\title{
Transatlantica
}

Revue d'études américaines. American Studies Journal

\section{The State of Comic Art Bibliography in North} America

\section{Michael Rhode}

\section{(2) OpenEdition}

1 Journals

\section{Electronic version}

URL: https://journals.openedition.org/transatlantica/4939

DOI: 10.4000/transatlantica.4939

ISSN: $1765-2766$

\section{Publisher}

Association française d'Etudes Américaines (AFEA)

\section{Electronic reference}

Michael Rhode, "The State of Comic Art Bibliography in North America", Transatlantica [Online], 1 । 2010, Online since 26 August 2010, connection on 10 February 2023. URL: http://

journals.openedition.org/transatlantica/4939 ; DOI: https://doi.org/10.4000/transatlantica.4939

This text was automatically generated on 10 February 2023

\section{(c) (i) (9)}

Creative Commons - Attribution-NonCommercial-NoDerivatives 4.0 International - CC BY-NC-ND 4.0 https://creativecommons.org/licenses/by-nc-nd/4.0/ 


\title{
The State of Comic Art Bibliography in North America
}

\author{
Michael Rhode
}

1 Within the past two decades, several American bibliographies of comic art have been published to aid in research on comics and cartooning. Professor John Lent's ten-volume Comic Art Bibliographies is one of the largest such projects and he began it with a self-published volume in 1986. ${ }^{1}$ Librarian Randy Scott published The Comic Art Collection Catalog: An Author, Artist, Title and Subject Catalog Of The Comic Art Collection, Special Collections Division, Michigan State University Libraries, ${ }^{2}$ which as its title makes clear, only deals with material held in one, albeit a very good, library. In the 1990s, Scott's project moved online and two other online bibliographies were started the Comics Research Bibliography by John Bullough and Michael Rhode, and Gene Kannenberg's Comics Scholarship Annotated Bibliographies. Although this paper concentrates on bibliography, it also examines indexes, checklists and catalogs of comic art. The differences in the forms are explained by Randy Scott as, "an 'index' is a pointer, a device that shows the way to something. A 'catalog' is a list of items in a given collection, and it will frequently be itself indexed. A 'bibliography' is a list of published works, also frequently indexed, but normally independent of a given physical collection of books." ${ }^{3}$ For our purposes, the technical terms can be interchangeable.

2 To create a bibliography of comic art, one must first define comic art. John Lent's view of comic art is a broad and inclusive one encompassing animation, comic books and strips, humorous art or illustration, caricature, gag cartoons, and political or editorial cartoons. Cartoonists themselves rarely draw any distinction when accepting work, but do so in professional groups like the National Cartoonists Society or the American Association of Editorial Cartoonists, or when giving awards like 
the Harveys or the Reubens. Examples of 'cross-genre' cartoonists abound in America - Jack Kirby, best known for his comic book superhero work, also did romance comic books, comic strips like Sky Masters and animation. Mike Peters does editorial cartoons and the strip Mother Goose and Grimm. Harry Bliss illustrates childrens books, and recently started a comic panel, but remains best known as a New Yorker gag cartoonist. Jules Feiffer wrote plays and screenplays, wrote The Spirit comic in the 1940s, was a long-time comic panel cartoonist in the Village Voice and now does children's books. J.C. Duffy, known for his comic strip The Fusco Brothers, broke into the New Yorker's gag cartoon market. Richard Thompson moved from caricature and spot illustrations for the Washington Post and the New Yorker to Richard's Poor Almanack, a weekly comics panel, added Cul de Sac as a weekly comic strip and just brought that strip into daily syndication.

${ }_{3}$ One of the main problems with comics research and bibliography for most of the twentieth century was the ephemeral nature of the source material. Comic strips and books were not taken seriously and kept, or collected annually like New Yorker or editorial cartoons were. The traditional library subject heading of 'American wit and humor, pictorial' unsurprisingly focuses on collections of gag and editorial cartoons and comic strips. The earliest piece in the Library of Congress, America's national library, is from 1849 - James Alexander Read's Journey to the gold diggins by Jeremiah Saddlebags, but the catalogue record gives the researcher no details about what it actually is. This heading only finds American books of course, but that is problematic since the study of comics is now multinational. This subject heading only found what a cataloguer responsible for multiple types of books put under it as well thus the Library of Congress only lists 1,945 books with this subject heading - a ridiculously small amount compared to what was most likely published. Only nine books between 1900 and 1920 are either catalogued with this subject heading or held by the Library. For 'Comic books, strips, etc.' the first entry is New fun [microform]: the big comic magazine apparently from 1935, but the microfilm is actually from decades later. ${ }^{4}$

4 Joseph Witek was able to sum up eighty years of one strain of writing about comics - serious critical or historical overviews - in his 1999 article, "Comics Criticism in the United States: A Brief Historical Survey," ${ }^{5}$ but such an overview would be very difficult for the period beginning in the 1980s. Witek's article reveals the paucity of such works, as he purposefully excluded those of the 1950s anti-comic book campaign typified by Frederic Wertham's Seduction of the Innocent, and those that he called "various fan discourses produced by and for comics enthusiasts." (p. 4) There is a strong tradition of covering various types of comic art in the popular press; one fine example is "Comics, Comix and Graphic Novels," a recent online bibliography compiled on Time Magazine by staff writer Andrew Arnold who found scores of articles. ${ }^{6}$ In his introduction, Arnold mentioned highlights such as Time's first comics story -- R.F. Outcault's 1928 obituary, twenty-one articles on Milton 
Caniff, and various cartoonists who made the cover such as Bill Mauldin and T.H. Webster. Modern technology has made a work like that possible though - Arnold was undoubtedly able to use Time's in-house databases to compile his work. Traditionally a comics bibliographer would have had to use sources like the aforementioned library catalogues and The Reader's Guide to Periodical Literature which even now captures very little of popular articles on comics. A recent search by the author for articles on Harvey Pekar at the time when a movie based on his life was coming out revealed very few - far less than had already been found through alternative means.

5 It took the academic attention paid to comic books in France and the concurrent rise in American fan culture to begin the process of compiling both original material and guides to it. The 1960s saw a rise of fan-based projects to collect and index primary sources such as Bill Blackbeard's San Francisco Academy of Comic Art, Jerry Bails' Who's Who in American Comic Books, and his friend Howard Keltner's Golden Age Comic Book Index. ${ }^{7}$ Blackbeard collected newspapers from around the country that were being discarded by libraries and preserved the comic strips in them. 275 boxes of his collection now reside in Ohio State University's Cartoon Art Library and have formed the basis for many comic strip reprint books over the past three decades. ${ }^{8}$ Can one really have a 'bibliography' of individual comic strips? Probably not, although you could have a index of a strip, or a bibliography of books about a strip. But a bibliography of comic books is certainly realistic. Jerry Bails took a similar approach to Blackbeard's for comic books -- buying older issues, microfilming them, and then reselling them to continue the project. While Blackbeard worked to reprint older, and sometimes forgotten, comic strips, Bails attempted to document the lives of the creators through a listing of their publications. In 1996, Bails wrote about the difficulties in studying comic books:

Throughout all the years I was in school, from 1938 to 1959, I thought I was the only screwball who took comics seriously. At 25 , I was convinced that I was the only adult in the world who cared about this medium, except those who had made it their professional career. Even the professionals I knew thought there was something a bit arrested about a grown man who loved comics. In those days, the pros themselves bought into the notion that comics were "only for kids." I think maybe that's an opinion I helped change. It has become almost canonical to date the beginning of Comics Fandom to numerous fannish events of 1961, but like every so-called beginning in history, Fandom has its precursors. ${ }^{9}$

Bails wrote of his project,

...the first edition of The Who's Who of American Comic Books was a 4-volume, softcover affair that appeared back in the period 1973-76.... I wanted to provide a biographical entry for every man and woman who contributed original work to the American comic book. I adopted the broadest possible definition of the genre. My catch was to include every known species of comic book -- from mainstream comics to all the alternatives. It even included a sampling of the most significant contributions of the small (vanity) press. Obscure comic book premiums, instructional comics -- even religious and propaganda comic books -- were to be part of the haul. Color was to be no barrier this time. No comic book was too large or too small, too elegantly bound or intricately disguised as a "non-comic-book" to 
slip through my net. If it came off the presses (or even from a copy machine) and was predominantly devoted to the presentation of features in the form of sequential panels -- representing the lapse of time, real or imagined -- I called it a "comic book." Oh, yes, like any good fish, it had to have a spine. Only the comic "wannabes" -- the cartoon calendars, the trading cards and the coloring books were disqualified -- but even they managed to slip into the database under the guise of collateral species (sister arts).

7 Bails's work survives him, and remains on the Internet as a good beginning site for those doing research on a comic book creator's work. ${ }^{10}$

These types of projects continued into the 1970s with Robert Overstreet's Overstreet Price Guide, George Olshevsky's Marvel Comics indexes, and the Amateur Press Association (Indexing) group APA- $\left.\right|^{11}$. Overstreet's guide is the first and most famous of the type of book that lists all the issues of a comic book, sometimes with information about them, and what purports to be a price that the comic book is worth. The book was initially a fan-based project with dozens of collectors contributing information on what comic books existed, and who worked on them. Overstreet will publish his $38^{\text {th }}$ edition in 2008 and other titles followed his lead including Maggie Thompson and the Comics Buyer's Guide's Comic Book Checklist and Price Guide (14 editions), Alex Malloy's Comics Value Annual, the Comics Buyer's Guide's Standard Catalog of Comic Books. Short-lived series such as The Comic Book Price Guide by Duncan A. McAlpine, What's It Worth? 1983 Price Guide to Comic Books (New York: Dell), the 1980's series The Official Price Guide to Comic and Science Fiction Books by Hudgeons and Rodger (Orlando: House of Collectibles), and the 1990's Wizard Magazine series Wizard Comic Book Price Guide Annual also have appeared and may have bibliographic uses, but with 38 editions, even if the first was a mimeographed booklet, Overstreet remains the standard. In recent years, the Overstreet Price Guide has featured a section on "Platinum" or pre-1938 comic books by Robert Beerbohm. Many of these books were barely known until Beerbohm began listing them, and his work remains a useful bibliography of them, if at times a bit too inclusive as anything with cartoon art might find itself considered a comic book. Another bibliography worth mentioning, the two editions The Slings \& Arrows Comic Guide ${ }^{12}$ edited by Frank Plowright, is actually a British product although about American comic books. This book attempts to critically rate comic book series and give details about them rather than take the price guide approach.

George Olshevsky took a different approach than Overstreet's and described the contents of each issue of a comic book, its creators, the characters and plot and what other stories it was linked to. His Marvel Comics Index vol. 1: The Amazing Spider-Man appeared in 1976, and was followed by eight other volumes (with a total of twelve books in them) before ending. Olshevsky and others continued this type of index for both Marvel and DC comics in the 1980s. APA-I was formed in 1977 by fans to index comics and share those indexes by mail. It still 
continues, although its role and membership has been attenuated by the Internet. Other fan projects have arisen - Allan Holtz's The Stripper's Guide is an attempt to list in a database every comic strip that ever ran in an American newspaper. Holtz circulated his database to subscribers first on paper, then on floppy disks and finally on cds. Currently he has a blog where he discusses strips. ${ }^{13}$ In a similar vein, Dave Strickler compiled Syndicated Comic Strips and Artists 1924-1995: The Complete Index (Cambia, CA: Comics Access, 1995). One of the largest fan-based bibliography projects is the Grand Comic Book Database (GCD). ${ }^{14}$ The GCD began as an offshoot of the APA-I and an attempt to create a searchable database of comics in 1994. Originally, disks of data were mailed between participants, but eventually the project migrated onto the web. As of 27 November 2007, the following statistics were true of the GCD: 3,919 Publishers/imprints; 26,435 Series (i.e. continuing characters); 324,863 books (112,266 indexed); 603,112 Story objects; $1,869,388$ credits and 161,091 covers. The GCD makes it very easy to check on the details of a comic book.

10 The rise of specialized comic book library collections has made research on comics easier while reflecting the increased academic respectability the field has moved towards, which of course also increased the amount of academic publications. Ohio State University's Cartoon Art Library and Michigan State University's Cartoon Art Collection both began in the early 1970s. In her 2001 IJOCA article, ${ }^{15}$ Curator Lucy Caswell notes, "[C]lipping files are particularly useful because at the present time much information related to cartoons is published in sources that are not indexed." Randy Scott's 2005 account $^{16}$ of the growth of the Michigan collection does not really discuss his online Index to and List of the Comic Art Collection which is a valuable source of bibliographic information. Like the 1993 published version, the online Index only lists material held in the library. However, one can go to the site, and work one's way to a heading for "Books about Comics" ${ }^{17}$ or "Reference Works on Comics"18 and see dozens of titles in small specialized bibliographies. The works of authors and artists can be tracked similarly, as can articles about comics that the Library holds. Scott has compiled an amazing resource, and interlibrary loan increases the use of it.

11 Along with Scott's Index, John Lent's monumental Comic Art Bibliographies are one of the major achievements of comics bibliography. Lent's 10-volumes total 85,106 citations arranged by continent, country, media and subject order. Statistics are the only way to begin to appreciate Lent's achievement. In the introduction to his last volume, he wrote:

All told, the ten volumes include 85,106 citations covering 144 countries. The United States accounted for 42,232 entries, broken down by comic books and comic strips, 25,416; and animation, gag, magazine, and political cartoons, 16,816. There were 26,172 sources on comic art of 41 European countries, 12,002 on 28 Asian countries, 2,306 on Central and South America's 17 countries; 1,118 on Canada; 790 on Africa (28 countries), 688 on Australia and Oceania (six islands); 409 on Middle East (11 countries), and 466 on 11 Caribbean territories. In the first four 
bibliographies, 29,105 citations appeared; the number increased to 56,001 in the most recent six books. ${ }^{19}$ frustratingly fugitive (like conference papers), but for a comics researcher they should be a first stop. Unfortunately a complete set of them costs about US $\$ 1000$. Lent also lists new books in his "The Printed Word" column in the International Journal of Comic Art (IJOCA) which appears bi-annually.

13 Independent of Lent's work, but inspired by the GCD, John Bullough proposed a comic bibliography project. Of all the GCD's participants, the author was the only person to work with him on the Comics Research Bibliography. ${ }^{20}$ Since 1996, Bullough and I have been combing various sources including newspaper archives, printed material and the Internet for citations about comic art. Bullough's academic career has led in a different direction than comics studies, but the website he hosts and maintains is still usable, if updated erratically. The update of October 2005 led to about 18,500 citations being included; the number should be far beyond that now. Several advantages of the Internet for bibliography exist: there is essentially an infinite amount of space; corrections can be made immediately; additions can be included on a timely basis; and metadata, or information not directly contained in the title, can be added to increase the usability of the citation. The utility of the searchable nature of such a bibliography cannot be overstated. Lent's bibliographic citations are tied to the term he chose to index at the moment, and thus 'Harvey Pekar' is separated from his 'American Splendor' comic book. In a searchable database with additional metadata, citations for both terms can be retrieved easily.

14 Gene Kannenberg chose a different approach for his Comics Scholarship Annotated Bibliographies. ${ }^{21}$ On the site, he states it "... primarily covers book-length works about comic books and comic strips, from "fannish" histories to academic monographs, providing detailed information and guidance on further research. Each entry will eventually include the book's Table of Contents as well as (if applicable) a list of comics works reprinted in it (and their sources, sometimes undocumented), other general notes on content and organization, ISBN numbers, and reviews..." Kannenberg's targeted approach can be more useful than Bullough \& Rhode's wider one when one is working on a specific issue.

15 It is evident that both computers and the Internet has changed the nature of comics bibliography in many ways - research to create them, access to articles cited in them and the growing degree of information that is known or can be found. Washington DC-area collector Warren Bernard has postulated a 'secret history of comics' in which works that famous cartoonists did for in-house corporate magazines and government publications need to be rediscovered as well as forgotten cartoonists and their works. Examples of this are You Kin Take It From Me, a small pamphlet Bill Mauldin did in 1942 or the cover that Percy 
Crosby did for January 1924's The Telephone News published by Bell Telephone of Pennsylvania. Bernard recently told me, "Comics historians generally have not really researched what comics people have done in magazines, focusing instead on their newspaper works. H.T. Webster did a monthly strip for American Magazine for over a decade. Parallel to that is the tremendous amount of material that was done by famous cartoonists in magazine ads. For example, George McManus was a spokesman for the coffee industry, and Bud Fisher promoted Goodyear Tires, so there is this whole world that most historians have not looked at." Bernard did note that Fantagraphics Books just published Where's Dennis?: The Magazine Cartoon Art of Hank Ketcham by Hank Ketcham, Alex Chun and Shane Glines.22 Another example is from the defense contractor $\mathrm{CACl}$; I recently discovered by chance that they have hired cartoonists for their in-house training manuals. The cartoonists they have used are 'Vip' aka Virgil Partch, followed by gag and Playboy cartoonist John Dempsey and then editorial cartoonist Chip Bok. ${ }^{23}$

Other material needing to have closer attention by bibliographers is 'grey literature.' Grey literature is printed material that is not easily available by subscription or produced by commercial publishers. Little of this material is collected by libraries, and even less is used by scholars. Examples in the comics field include the ICv2Retailers Guide, the Guide's predecessor, Capital Comics' Internal Correspondence and Diamond's monthly Previews catalogue, Dateline weekly newsletter and monthly Dialog magazine. Krause's Comics \& Games Retailer monthly magazine could probably be added. These publications are all meant for the professional comic book retailer in America, numbering under 3000 at this point. Fewer than 200 issues of all of these titles, in a period covered by twenty years, are available in the Michigan State University Comic Art Collection, and very few have the articles in them included in a bibliography. Material like this is easier to discover than ever before due to Amazon and other specialized booksellers like ABE or Bibliofind. One can now discover unknown works by a cartoonist purely by putting a name into a site selling material - even eBay.

Checklists can be useful too, although they are not considered 'pure' bibliographies. I feel that being able to find work by cartoonists, including advertisements or spot illustrations, is frequently as useful as finding a short article that may have mentioned one's name in passing. Examples of checklists are Carl Richter's Crumb-ology: The Works of R.Crumb 1981-1994 (Sudbury, MA: Water Row Press, 1995) and J. Olivier Dancoine's self-published Charles Vess: From the 1970's to 1996 (Paris, 1997). As one could expect, finding an individual checklist can frequently be difficult. Some companies are publishing their own checklists of multiple story events such as Marvel's Civil War series, or DC Comics 30 Essential Graphic Novels (2007), or Wizard's Top 100 Trade Paperbacks of All Time (2006) Free Comic Book Day giveaway. Several bibliographies of comic books have been marketed to a library audience including The 101 Best Graphic Novels by Stephen Weiner (New York: NBM, 2006), his earlier 100 Graphic Novels for Public Libraries (Kitchen Sink Press, 1995), 
and Graphic Novels: A Bibliographic Guide to Book-Length Comics by D. Aviva Rothschild (Librarians Unlimited, 1995). All are bibliographies, but also grist for the bibliographer's mill.

An interesting case study in what might be termed 'comic strip bibliography,' although the very existence of such a thing was questioned earlier in this article, can be seen in Robert Mankoff's work. Mankoff is the cartoon editor of the New Yorker magazine. Mankoff had an idea to individually catalogue cartoons online by subject and topic and then to sell reproductions of them. The result of his idea was The Cartoon Bank, which was eventually bought by the New Yorker. ${ }^{24}$ Mankoff took his experience with The Cartoon Bank, and digitized and catalogued the New Yorker's cartoon collection which previously had been searchable in their library only through scrapbooks of cartoons arranged by the names of individual cartoonists. ${ }^{25}$ This searchable database made possible books like The Complete Cartoons of the New Yorker edited by Mankoff (Black Dog \& Leventhal Publishers, 2004) and also topical volumes like You Had Me at Bow Wow: A Book of Dog Cartoons by New Yorker Cartoonist Jack Zeigler (Vendome Press, 2006) and The New Yorker Book of Teacher Cartoons by Robert Mankoff (Bloomberg, 2006) while making obsolete specialized checklist volumes such as TelevisionRelated Cartoons in the New Yorker Magazine: Over 1250 Cartoon Descriptions (1950 Through 1990 Indexed By Cartoonist and Subject) by Ronald L. Jacobson (McFarland, 1993). Additionally through the Cartoon Bank, volumes are produced for commercial clients and will not appear in any bibliography unless a collector happens to acquire one.

It ishould be apparent that much remains to be done in comics bibliography. Scholarship in comics has increased in the past 15 years, possibly due to conferences like Popular Culture Association and the International Comic Arts Festival/Forum. Also the number of popular articles has increased exponentially partly due to increased commercialization and media, and the upswing in popularity of animation especially prime-time animation like the Simpsons. The popularity of graphic novels changed academic thinking about comics while manga and anime have swept over the country as popular media. Including spinoffs like movies, comic art has become a billion dollar industry, which makes it more legitimate and worthy of study. ${ }^{26}$ Future problems with comics bibliography can be seen, if not yet solved. Is videogame animation suitable for inclusion? In addition to previously mentioned effects, another way the Internet has changed comics bibliography is the overwhelming amount of material - does one include blogs, YouTube videos, podcasts, online fanzine and radio shows, in one's bibliography? Many of these feature interviews with cartoonists. The interactive nature of the Web $2.0^{27}$ means that more and more original and useful material will not be generated by traditional media. How can one keep up with the explosion of comics magazines and the fanzine press like Vanguard and TwoMorrows which are publishing biographies as well as themed magazines? Neither John Lent nor I subscribe to Wizard or list its articles in our bibliographies, while Michigan State collects but 
does not index it - a fatal flaw to some, and not a situation to be desired in any event. Should articles on Internet news sites like Tom Spurgeon's The Comics Reporter, Jennifer Contino's The Pulse, Heidi MacDonald's The Beat and Matt Brady's Newsarama be catalogued? At this point, I am only listing interviews on these sites in the Comics Research Bibliography, but that is just a function of practicality. One may hope that search engines such as Google will handle the research, but they return such unmediated searches as to be almost useless on a specialized topic. An example would be trying to find information on a cartoonist named Coulter who illustrated Gobbledygook Has Got To Go, for the Bureau of Land Management, circa 1970;28 a search returns no useful information. What should one do about vanished articles or websites when a link no longer works? The Internet Archive will sometimes provide the vanished page; right now that is about the only option. Print on Demand sites like Lulu.com, while increasing the amount of comics material available, have mostly included self-published comics, especially collections of web or Internet comics. However in Summer 2007, Universal Press Syndicate began publishing mainstream comic strip books through them when Andrews McMeel declined the book. Books from the strips Clear Blue Water, The Fusco Brothers, Overboard, PreTeena and Stone Soup were published through Lulu.com's service and it may be increasingly hard for both libraries and bibliographers to know what strip collections exist. ${ }^{29}$

Even the increasing coverage in mainstream media makes the bibliographer's task difficult - on a given day, the New York Times -which has begun slowly running comics of its own like James Stevenson's Lost and Found New York pages - may have four or five articles on aspects of comic art. Different versions may exist in print and online; the Onion does this regularly with their cartoonist interviews as did this recent example of Christopher Porter's interview with animation writer Brendon Small -- "Brutally Hilarious: 'Metalocalypse' is a double-devilhorns delight on Adult Swim," Express (November 26, 2007) is the printed version, while an extended one is online as "Brutally Funny: 'Metalocalypse.'" ${ }^{30}$ Against that trend is one where people compile their own lists on Amazon.com such as "New Yorker cartoons, hardcover and paperback; A Listmania! List" by B. Reese and Tom Spurgeon puts online Books About Comics," "a list I'm making for no good reason of books about comics, with an emphasis on criticism and history." Beth DaviesStofka publishes an annual web column, "Best Comics Scholarship," 32 while John Lent and I are discussing adding a third issue to the IJOCA's publishing schedule which would be a bibliography of the previous year's publications on comics. So like any other field, comics bibliography will continue to grow, although not as quickly or in all the directions a comics scholar could hope for. And like any other field, a final bibliography including everything on the subject, will never be possible - fortunately for those of us working in the field. A field that does not have a growing bibliography is a dead field, so comic art studies must be relatively healthy. 


\section{NOTES}

1. Lent, John A. Comic Art, an International Bibliography. Drexel Hill, PA, 1986.

2. Scott, Randall W. The Comic Art Collection Catalog : an author, artist, title and subject catalog of the Comic Art Collection, Special Collections Division, Michigan State University Libraries. Westport, CT: Greenwood Press, 1993.

3. Scott, Randy. "The Reading Room Index to the Comic Art Collection: A Descriptive Manual" unpublished manuscript dated 28 March, 2007.

4. Randy Scott's Comics Librarianship: A Handbook, Jefferson, N.C.: McFarland and Co., 1990, goes into these issues in far more detail and the foreword by Sanford Berman is particularly useful for its summation of the problem of finding comics in libraries.

5. International Journal of Comic Art 1:1, Spring/Summer 1999: 4-16.

6. Online at http://www.time.com/time/archive/collections/0,21428,c_comics, $00 . s h t m l$

7. A revised edition of Keltner's work tracking the appearances of superheroes and other continuing characters in comic books was self-published in 1998.

8. See http://cartoons.osu.edu/finding_aids/sfaca/ for more details on the Library's holdings.

9. The Panelologist (the electronic edition) 16: 1, Spring, 1996, Published in conjunction with the second edition of The Who's Who Of American Comic Books by Jerry G. Bails.

10. See http://www.bailsprojects.com/

11. See Michigan State University's Cartoon Art Collection Index at http://www.lib.msu.edu/ comics/rri/arri/ap.htm for information on the contents of some of the APA-I mailings.

12. $1^{\text {st }}$ edition - Aurum Press, 1997; $2^{\text {nd }}$ edition - Top Shelf Productions, 2003.

13. See Stripper's Guide at http://strippersguide.blogspot.com/

14. At http://www.comics.org. For more history of the GCD, see Rhode, Michael and Ray Bottorff Jr. "The Grand Comics Database (GCD): An Evolving Research Tool," IJOCA 3:1, Spring 2001: 263-274.

15. "The Ohio State University Cartoon, Graphic, and Photographic Arts Research Library," Inks 1:1, February 1994: 34-37 and Caswell, Lucy Shelton. "Resources for Scholars at The Ohio State University Cartoon Research Library," IJOCA 3:1, Spring 2001: 251-262; quote from p. 255.

16. Scott, Randall W. "Beginnings and Landmarks: The Comic Art Collection at the Michigan State University Libraries and My Career." IJOCA 7:2, Fall 2005: 68-77.

17. At http://www.lib.msu.edu/comics/rri/brri/books_a.htm\#babcom

18. At http://www.lib.msu.edu/comics/rri/rrri/reef.htm\#rwoc

19. Lent, John A. Comic Books and Comic Strips in the United States through 2005: An International Bibliography. Praeger Publishers, 2006: vii-viii.

20. At http://www.rpi.edu/ bulloj/comxbib.html

21. At http://www.comicsresearch.org/

22. Private conversation, 27 November 2007.

23. For examples, see http://comicsdc.blogspot.com/2007/11/vip-bok-ware-and-fish-nchips.html

24. See http://www.cartoonbank.com/

25. As explained by Mankoff in a presentation at the Smithsonian American Art Museum, 3 June 2007.

26. Many of the ideas in this paragraph are a result of a brainstorming conversation between John Lent and the author.

27. See http://en.wikipedia.org/wiki/Web_ 2 for a basic definition of the Web 2.0 concept.

28. See http://comicsdc.blogspot.com/2007/11/gobbledygook-by-coulter.html for illustrations from the book. 
29. Astor, Dave. "Two Print-On-Demand Books Feature Universal Comics." E\&P Online 20 July 2007, $\quad$ http://www.editorandpublisher.com/eandp/departments/syndicates/ article_display.j\sp?vnu_content_id=1003614777 ; "More Print-on-Demand Books From Lulu.com/Universal." E\&P Online 29 August 2007, http://www.editorandpublisher.com/ eandp/departments/syndicates/article_display.j/sp?vnu_content_id=1003632695; “'PreTeena' Paperback Published.” E\&P Online 21 August 2007, http:// www.editorandpublisher.com/eandp/departments/syndicates/article_display.j\sp? vnu_content_id=1003628605;" 'Stone Soup' Book From Lulu.com and Universal." E\&P Online 19 September 2007, http://www.editorandpublisher.com/eandp/departments/ syndicates/article_display.jlsp?vnu_content id=1003642963.

30. At http://www.readexpress.com/read freeride/2007/11/ brutally funny metalocalypse.php

31. At http://www.comicsreporter.com/index.php/lists/lists_and links/87/

32. Broken Frontier, 8 January 2007, http://www.brokenfrontier.com/columns/ details.php?id $=590$

\section{AUTHOR}

\section{MICHAEL RHODE}

mrhode@gmail.com 